\title{
Peningkatkan Aktivitas Dan Hasil Belajar Matematika Materi Statistika Dengan Metode Eksperimen
}

\author{
Daryono Mardi Sulistiyo(1) \\ SMP N 3 Teras Boyolali \\ daryono@gmail.com
}

DOI: 10.23917/varidika.v32i2.13005

Submission
Track:
Received:
20 October 2020
Final Revision:
20 November 2020
Available online:
24 December 2020
Corresponding Author:
Daryono Mardi Sulistiyo(1)
daryono@gmail.com

Submission

ABSTRAK

Penelitian ini bertujuan untuk mengetahui apakah metode eksperimen dapat meningkatkan aktivitas dan hasil belajar matematika materi statistika. Subjek penelitian adalah siswa kelas VIII B SMP Negeri 3 Teras tahun pelajaran 2019/2020sebanyak 30 siswa. Penelitian ini adalah penelitian tindakan kelas dengan metode experimen yang dilaksanakan dalam 2 siklus. Hasil penelitian menunjukkan bahwa aktivitas belajar siswa pada kondisi awal dan kondisi akhir pada materi statistika mengalami peningkatan. Siswa yang tampak tidak bergairah dan bermalas-malasan belajar berkurang dari banyak menjadi hampir tidak ada. Hal ini disebabkan karena selama proses pembelajaran siswa terlibat aktif bekerja melakukan praktikum sehingga tidak ada kesempatan untuk bermalas-malasan. Hasil belajar matematika materi statistika setelah diberikan proses pembelajaran pada siklus II meningkat. Ketika diberikan ulangan harian (tes) pada kondisi awal, nilai tertinggi yang diperoleh siswa adalah 80 berjumlah 5 anak, sedang pada siklus II (kondisi akhir) nilai tertinggi yang diperoleh siswa 100 berjumlah 5 anak. Nilai terendah pada kondisi awal sebesar 45 dan pada siklus II (kondisi akhir) sebesar 65 yang juga meningkat. Nilai rata-rata kelas meningkat signifikan dari 55 pada kondisi awal menjadi 70 pada siklus II (kondisi akhir) yaitu sebesar 21,43\%. Hal ini sudah memenuhi harapan untuk mencapai batas KKM (Kriteris Ketuntasan Minimal) sebesar 65.

Kata kunci: matematika, statistika, metode eksperimen, aktivitas, hasil belajar

\section{PENDAHULUAN}

Keaktifan siswa dalam proses belajar mengajar menentukan keberhasilan mereka dalam menyelesaikan atau mencapai tujuan pembelajaran. Keaktifan terkait dengan aktvitas, baik di 
sekolah maupun di luar sekolah. Siwa yang aktif merespon perintah guru secara benar akan lebih banyak suksesnya. Adapun yang dimaksud aktif adalah siswa berani bertanya, mempertanyakan, dan mengemukakan gagasan kepada guru atau sewaktu ada kegiatan pendidikan. Depdiknas (2007: 1) menyatakan aktif maksudnya adalah bahwa dalam proses pembelajaran guru harus menciptakan suasana sedemikian rupa sehingga siswa aktif bertanya, mempertanyakan, dan mengemukakan gagasan. Proses pembelajaran yang dilakukan di dalam kelas merupakan aktivitas mentransformasikan pengetahuan, sikap, dan ketrampilan (Martinis Yamin, 2007: 75). Aktivitas merupakan prinsip atau asas yang sangat penting dalam interaksi belajar mengajar (Sardiman, 2006: 96). Saat pembelajaran belangsung siswa mampu memberikan umpan balik terhadap guru.

Idealisme semacam itu tentunya yang diharapkan dalam kegiatan belajar mengajar untuk semua mata pelajaran. Namun ketika di kelas dengan kondisi siswa yang berbeda hal tersebut banyak mengalami kendala. Salah satu contoh ketidakidealnya terjadi di sekolah SMP Negeri 3 Teras Boyolali. Pada mata pelajaran Matematika materi statistika siswa mengalami kendala dalam menyerap ilmu yang diberikan oleh guru.

Aktivitas dan hasil belajar matematika tentang statistika tergolong masih rendah. Hal ini bisa disebabkan karena materi statistika merupakan awal pembelajaran matematika di kelas delapan. Beberapa bukti yang menunjukkan aktivitas belajar siswa masih rendah antara lain sebagai berikut: (1) siswa tampak kurang antusias dalam mempelajari materi statistika; (2) pada waktu diberikan tugas beberapa siswa masih belum bisa menyelesaikan tugasnya dengan baik; (3) beberapa siswa merasa mata pelajaran matematika tidak menarik dan sulit; (4) ketika diberikan tugas untuk mengolah data, membuat tabel, membuat grafik banyak siswa yang belum bisa. Nilai ulangan harian (tes), nilai tertinggi yang diperoleh siswa adalah 80 , nilai terendah 45, dan nilai rata-rata kelas 55. Hal ini belum mencapai batas KKM (Kriteris Ketuntasan Minimal) sebesar 65. Selanjutnya penelitian ini dilakukan berangkat dari permasalahan berikut: apakah melalui metode eksperimen dapat meningkatkan aktivitas belajar matematika dan hasil belajar pada materi statistika bagi siswa kelas VIII B SMP Negeri 3 Teras pada semester 2 tahun pelajaran 2019/2020. Adapun tujuan penelitian ini adalah ingin melihat keefektifan metode eksperimen dalam pembelajaran matematika materi statistika baik itu aktivitasnya maupun hasil belajarnya. 


\section{METODE}

Tempat penelitian di kelas VIII B SMP Negeri 3 Teras Boyolali yang beralamat di desa Tawangsari, kecamatan Teras, kabupaten Boyolali. Untuk memperoleh data awal peneliti menggunakan teknik dokumentasi. Untuk pengumpulan data pada siklus I dan siklus II dilakukan teknik observasi yaitu untuk memperoleh data tentang aktivitas belajar siswa. Untuk pengumpulan data yaitu untuk memperoleh data hasil belajar siswa pada siklus I dan siklus II dilakukan tes tertulis. Tes tertulis merupakan ulangan harian yang diberikan setiap KD. Nilai yang diperoleh siswa merupakan sumber data hasil belajar siswa. Alat pengumpulan data dalam penelitian ini ada enam yaitu a) dokumen catatan personal siswa untuk sumber data tentang motivasi belajar siswa pada kondisi awal, b) dokumen daftar nilai untuk memperoleh data hasil belajar siswa kondisi awal, c) lembar observasi untuk mengumpulkan data motivasi belajar siswa ntuk siklus I, d) butir soal tes untuk memperoleh data hasil belajar siswa pada siklus I, e) lembar observasi untuk mengumpulkan data motivasi belajar siswa untuk siklus II, dan f) ) butir soal tes untuk memperoleh data hasil belajar siswa pada siklus II.

\section{HASIL PENELITIAN}

Aktivitas belajar siswa kondisi awal (pra siklus) dengan siklus II dapat dilihat pada tabel berikut.

Tabel 1

Aktivitas belajar siswa materi statistika pada kondisi awal dengan kondisi akhir

\begin{tabular}{|c|c|c|c|}
\hline No & Kondisi awal & Siklus I & Siklus II \\
\hline 01 & $\begin{array}{l}\text { Masih banyak siswa yang } \\
\text { pasif }\end{array}$ & $\begin{array}{l}\text { Siswa yang pasif } \\
\text { berkurang }\end{array}$ & $\begin{array}{l}\text { Siswa yang pasif } \\
\text { sedikit }\end{array}$ \\
\hline 02 & $\begin{array}{l}\text { Sebagian besar siswa } \\
\text { tidak berani bertanya atau } \\
\text { menjawab pertanyaan } \\
\text { Dalam diskusi hanya }\end{array}$ & $\begin{array}{l}\text { Sebagian kecil saja siswa } \\
\text { yang tidak berani } \\
\text { bertanya atau menjawab } \\
\text { pertanyaan }\end{array}$ & $\begin{array}{l}\text { Sebagian kecil siswa } \\
\text { tidak berani bertanya }\end{array}$ \\
\hline 03 & $\begin{array}{l}\text { siswa tertentu saja yang } \\
\text { aktif } \\
\text { Sebagian besar siswa }\end{array}$ & $\begin{array}{l}\text { Dalam diskusi agak } \\
\text { banyak siswa yang aktif }\end{array}$ & $\begin{array}{l}\text { Dalam diskusi banyak } \\
\text { siswa yang aktif }\end{array}$ \\
\hline 04 & $\begin{array}{l}\text { hanya diam saja, takut, } \\
\text { malu, atau tidak } \\
\text { percaya diri }\end{array}$ & $\begin{array}{l}\text { Sebagian kecil saja siswa } \\
\text { yang masih diam saja, } \\
\text { takut, malu, atau tidak } \\
\text { percaya diri. }\end{array}$ & $\begin{array}{lr}\text { Hampir tidak ada } \\
\text { siswa tampak tidak } \\
\text { bergairah } & \text { dan } \\
\text { bermalas-malasan } & \\
\text { belajar } & \end{array}$ \\
\hline
\end{tabular}


Hasil belajar dari siswa pada kondisi awal dengan kondisi akhir dapat dilihat pada tabel berikut.

Tabel 2

Nilai ulangan harian siswa kondisi awal dan kondisi akhir

\begin{tabular}{|c|l|c|c|}
\hline No & Uraian & Nilai UH pra Siklus & Nilai UH siklus II \\
\hline 01 & Nilai terendah & 45 & 65 \\
02 & Nilai tertinggi & 80 & 100 \\
03 & Nilai rerata & 55 & 70 \\
\hline
\end{tabular}

Nilai ulangan harian pada kondisi awal dan kondisi akhir juga dapat dilihat pada gambar diagram berikut.

Gambar 1

Diagram batang nilai ulangan harian kondisi awal dan siklus II

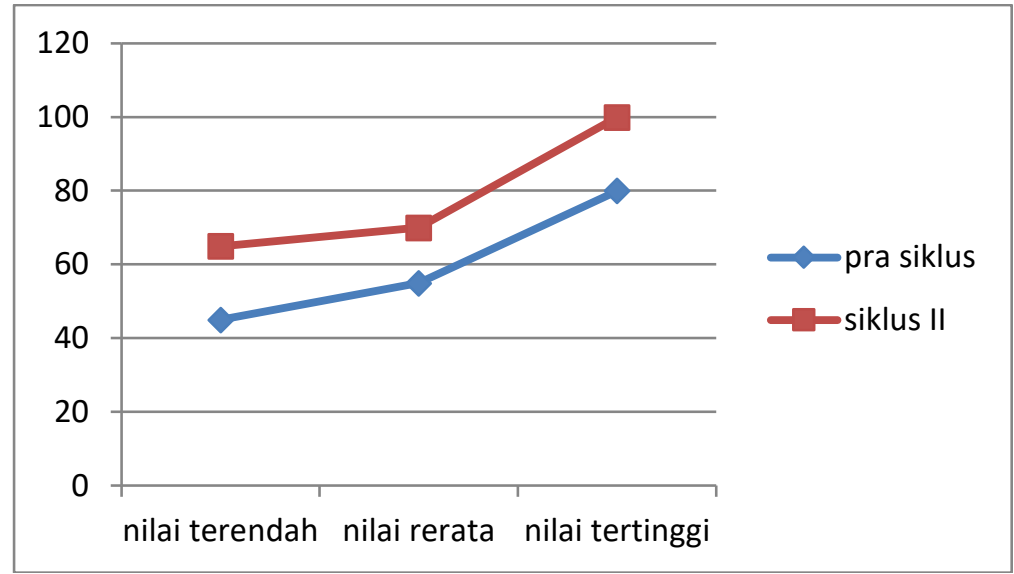

\section{PEMBAHASAN}

Metode eksperimen telah banyak digunakan dalam penelitian pendidikan. Azmi (2015) dalam penelitiannya yang menggunakan metode eksperimen dalam upaya meningkatkan hasil belajar fisika mengatakan bahwa kelas eksperimen yang diberi perlakuan model pembelajaran berbasis masalah dengan metode eksperimen lebih aktif dibandingkan kelas kontrol yang diberi pembelajaran konvensional. Siswa pada kelas eksperimen aktif dalam mengumpulkan data secara lengkap guna memecahkan masalah yang dihadapai. Pada awal pembelajaran siswa diberi masalah dalam lembar kegiatan siswa (LKS) terkait materi kalor yang diajarkan. Masalah yang dikemukakan kepada siswa tersebut dapat membangkitkan pemahaman siswa terhadap masalah, kesadaran adanya kesenjangan, pengetahuan, tujuan keinginan memecahkan masalah, 
dan persepsi bahwa mereka mampu memecahkan masalah. Penelitian Azmi ini sejalan dengan apa yang kami lakukan yakni metode eksperimen dapat meningkatkan aktivitas belajar dan hasil belajar pada mata pelajaran Matematika dengan materi Statistika. Dengan demikian metode eksperimen cocok dipakai dalam upaya meningkatkan hasil belajar. Dari gambar juga dapat diketahui bahwa nilai ulangan harian juga mengalami perubahan baik.

Dilihat dari hasil penelitian yang dikemukakan dalam tabel 1 dan 2 di atas diketahui bahwa pada perjalanan siklus selalu menunjukkan perubahan baik, misalnya dari yang tidak aktif menjadi aktif, dari yang tidak bergairah menjadi bergairah, dari nilai rendah menjadi nilai tinggi.

\section{SIMPULAN}

Berdasarkan hasil penelitian disimpulan bahwa metode eksperimen dapat meningkatkan aktivitas belajar dan hasil belajar matematika pada materi statistika bagi siswa kelas VIII B SMP Negeri 3 Teras pada semester 2 tahun pelajaran 2019/2020. Terkait aktivitas belajar, siswa yang pasif lebih sedikit sehingga terjadi perubahan yakni setelah dilakukan tindakan siswa menjadi banyak yang aktif, sebagian kecil siswa tidak berani bertanya atau sekarang siswa menjadi banyak yang bertanya, baik dalam diskusi maupun aktivitas kelas. Terkait dengan hasil belajar, disimpulkan bahwa perubahan nilai ulangan harian menjadi lebih baik, yakni dari 45 menjadi 65, yang awalnya 80 menjadi 100, dan 55 menjadi 70. Dengan demikian metode eksperimen dapat digunakan dalam meningkatkan aktivitas dan hasil belajar siswa.

\section{SARAN}

Saran kepada siswa. kegiatan pembelajaran dengan metode eksperimen dapat meningkatkan aktivitas belajar dan kegairahan belajar, karena bisa menarik perhatian siswa. Kegiatan pembelajaran dengan metode eksperimen akan menimbulkan suasana belajar partisipatif dan menjadi lebih hidup, maka hasil belajarnya pun meningkat. Saran kepada guru, diharapkan para guru menambah wawasan pemilihan metode pembelajaran sesuai dengan konsep yang diajarkan sehingga menciptakan situasi belajar mengajar yang efektif dan efisien.

\section{DAFTAR PUSTAKA}


Abin syamsudin Makmun, 2000, Psikologi kependidikan, Bandung: PT. Remaja Rosdakarya. Azmi, Aziz, Joni Rokhmat, dan Kosim, 2015. Pengaruh Model Pembelajaran Berbasis Masalah Dengan Metode Eksperimen Terhadap Hasil Belajar Fisika Siswa Kelas X Sman 1 Gunungsari Kabupaten Lombok Barat Tahun Pelajaran 2014/2015 dalam jurnal Pendidikan Fisika dan Teknologi (ISSN. 2407-6902) Volume I No 3, Juli 2015.

Depdiknas, 2003, Panduan Pengembangan Pembelajaran IPA Terpadu SMP/MTs. Jakarta: Pusat Kurikulum, Balitbang Depdiknas.

Depdiknas, 2003. Undang-Undang Republik Indonesia Nomor 20 Tahun 2003 tentang Sistem Pendidikan Nasional. Jakarta: Dirjen Dikdasmen.

Hamalik, Oemar. 2002 Psikologi Belajar dan Mengajar. Bandung : Sinar Baru Algesindo.

Hamidi, 2004. Metode Penelitian Kualitatif. Malang: UMM Press.

Joni, T.R (1992/1993) Pendekatan Cara Belajar Siswa Aktif: acuan konseptual peningkatan mutu kegiatan belajar mengajar. Naskah disiapkan untuk penataran Penyesuaian Tenaga Akademik FKIP Universitas Terbuka.

Majid Abdul. 2005. Perencanaan Pembelajaran. Bandung: PT. Remaja Rosdakarya.

Moleong J. Lexy. 2007. Metodologi Penelitian Kualitatif. Bandung: P.T. Remaja Rosdakarya.

Sumadi Suryabrata, 1998, Psikologi Pendidikan, Jakarta: PT. Raja Grafindo Persada. 